\title{
Sugar Content and Physical Characterization of Four Selected African Nightshade (Solanum nigrum) Edible Berries
}

\author{
Elijah H. Kamau, Julius M. Mathara, and Glaston M. Kenji
}

\begin{abstract}
Fruits constitute a major part of the diet in many parts of the world, highly recommended for the nutritional value derived from them. Fruit maturity is an important determinant of the quality as it affects the appearance, an aspect of quality considered by most consumers. Sugar content, colour, size and firmness are some of the quality indicators associated with maturity. While the ripening and maturity indicators are well documented for climacteric fruits, non-climacteric fruits such as berries lag behind. African nightshade (Solanum nigrum L.) edible berries are among them. This study evaluated the quality parameters of the edible berries of four varieties of African nightshade and found out that they accumulate glucose and fructose as they ripen with glucose being the most abundant sugar. Sucrose is only present during the senescence stage. Size remained relatively constant within each variety while firmness decreased progressively after veraison. Black NS differed with the others in colour besides fructose and sucrose content at 29.35 and $388.40 \mathrm{mg} / 100 \mathrm{~g}$, respectively. Giant NS recorded the highest glucose content at $172.44 \mathrm{mg} / 100 \mathrm{~g}$ when ripe. Conclusively, the African nightshade berries are characteristically similar to other non-climacteric fruits adopted as part of the normal diet and should be considered as a valuable addition to the diet.
\end{abstract}

Index Terms - Berries, African nightshade, Ripening, Firmness, Colour.

\section{INTRODUCTION}

Fleshy fruits are classified into climacteric and nonclimacteric types and they are important worldwide crops accounting for a major fraction of the world's agricultural output as well as a major component of the diet [1]. Quality of fresh fruits and their products is a function of a combination of various attributes which give value in terms of human food [2]. The importance of each of the quality attributes is determined by the commodity and its intended use and this often varies amongst producers, handlers and consumers. These qualities include but are not limited to appearance, firmness and shelf-life [2-3]. Final fruit quality and storage life are largely affected by the fruit maturity at harvest [2].

Maturation is the developmental stage leading to attainment of physiological maturity [4-5]. Immature fruits

Published on May 21, 2020.

Elijah H. Kamau, Department of Food Science, University of Eldoret Kenya.

(email: ekellyne@gmail.com)

Julius M. Mathara, Department of Food Science, Jomo Kenyatta University of Agriculture \& Technology, Kenya.

(email: jmmathara@jkuat.ac.ke)

Glaston M. Kenji, Department of Food Science, Jomo Kenyatta University

of Agriculture \& Technology, Kenya.

(email: mwakenji@agr.jkuat.ac.ke) are of an inferior quality since they are more prone to mechanical damage and shriveling besides having an inferior flavor [3]. Overripe fruits, on the other hand, are likely to be soft and mealy with an insipid flavor. Proper timing during fruit picking is important as early or late picking can lead to physiological disorders during storage [3].

For most fruits, advances in maturity are accompanied by several coordinated physiological, biochemical and structural processes $[1,4,6]$. These processes lead to changes in colour, size and chemical composition of the fruits. Various studies have addressed the metabolism of sugars and changes in biochemical and physiological properties in apples [7], sea buckthorn fruits [8-9], strawberries [1], pomegranate [4,10-11] and grapevines [12-14] among others. These studies documented the increase in size, change in skin colour, softening and changes in sugar fractions of the respective fruits.

Despite these advances in understanding fruit ripening, Jia et al. [1] observed that the regulation of ripening in the fleshy fruits is not well understood while [13] opined that control of berry ripening is still not well documented especially for the non-climacteric fruits. This is also true for the edible berries of African nightshade (Solanum nigrum L.) which, for long, have not been explored as a food item [15]. The documented information has described the crop as a leafy vegetable and therefore the fruits have not been given much attention. Few studies, however, have analyzed specific parts of the African nightshade berries such as the seeds and skin [16] and proven that they have a nutritional value that is comparable to other fruits that are regularly consumed in the diet. However, these studies were not controlled, the berries were mainly harvested in the wild and they did not address the changes during berry development and ripening. This study addresses this knowledge gap by using controlled trials to document the changes in the African nightshade berries during the ripening process, keen to evaluate the possibility of incorporating them in the household diet.

\section{MATERIALS AND METHODS}

\section{A. Sample Preparation}

Four varieties of the African nightshade (Solanum nigrum L.) were planted in the experimental field at the University of Eldoret. The Completely Randomized Design (CRD) was employed during planting on site as described by Bvenura and Afolayan [17]. There were four (4) blocks each subdivided into three (3) subplots to allow for three replications. Within the main blocks, there were subplots 
about $4 \mathrm{~m}$ by $2 \mathrm{~m}$ in size. These were separated by margins of about $1 \mathrm{~m}$ within the replicate blocks. The distance between blocks was about $1.5 \mathrm{~m}$. Four selected varieties of African nightshade were planted in the plots. These comprised of Giant Nightshade (Simlaw seeds), Black Nightshade - local variety (Simlaw seeds), Improved variety (JKUAT), Agriculture variety (KARLOKakamega). These were planted with a spacing of about $60 \mathrm{~cm}$ by $45 \mathrm{~cm}$. Drip irrigation was installed within the plots and appropriate crop husbandry was employed till the berries ripened at 12 weeks. Berries for the analyses were picked at four ripening stages; green, colour break, ripe and at senescence.

\section{B. Sugars}

Sugars were analyzed as described by Ribera-Fonseca, Noferrini, Jorquera-Fontena and Rombola [18] using the high performance liquid chromatography (HPLC). The samples were prepared by grinding about $10 \mathrm{~g}$ of the berries and placing this in a $100 \mathrm{ml}$ conical flask. This was followed by addition of $50 \mathrm{ml}$ of $96 \%$ ethyl alcohol. After refluxing this mixture for 1 hour at $1000 \mathrm{C}$, the slurry was filtered and the conical flask rinsed with $5 \mathrm{ml}$ of $80 \%$ ethyl alcohol. This filtrate was then evaporated at $600 \mathrm{C}$ to attain dryness before being dissolved in $10 \mathrm{ml}$ of distilled water. From this solution, $2 \mathrm{ml}$ was taken and combined with $2 \mathrm{ml}$ acetonitrile. This was then filtered through a 0.45 microfilter and placed in vials, ready for injection into the HPLC system.

\section{Firmness}

Berry firmness was determined as described by Lee and Lee [19] using the Rheometer (Compac-100, Sun Scientific Co., Japan). The mode was set at 20 with maximum load of 10 $\mathrm{kg}$ and $\mathrm{R} / \mathrm{H}$ hold of $2.0 \mathrm{~mm}$ and the $\mathrm{P} / \mathrm{T}$ press was set at 300 $\mathrm{mm} / \mathrm{min}$. For each ripening stage of each variety of African nightshade, the measurements were taken in 5 replicates.

\section{Size}

Berries' seizes were determined using the method described by Li et al. [20] using Vernier calipers. Fruits were chosen at random from each variety at each stage of ripening with the fruits in the mid-upper parts of the shoot being the most preferred. This measurements were taken 5 times for each variety at each of the four ripening stages and the mean values obtained.

\section{E. Colour}

Berry colour was determined using the method by Leite et al. [21]. This was done using a colour spectrophotometer (Model CR - 200 - Minolta, Japan). The parameters L* for lightness, $\mathrm{a}^{*}$ for redness and $\mathrm{b}^{*}$ for yellowness were recorded with a white tile used as a reference. All the values were taken in triplicate.

\section{F. Statistical Analyses}

Data was analyzed using the one way Analyses of Variance (ANOVA) using Genstat Version 14. The means were separated using Tukey's significance difference test using a probability value of $\mathrm{P} \leq 0.05$.

\section{RESULTS AND DISCUSSIONS}

\section{A. Sugars}

Berry sugars observed a rapid accumulation in the last stages of ripening which could be associated with upregulation of sugar-related genes such as cell wall invertases, hexose transporters and vacuolar invertases $[6$, 22]. The content of fructose in most of the berries increased from the green to ripe stage and then observed a decline. KARLO Agric. showed the sharpest decline at this stage. Black NS was exceptional from this trend as the content peaked at colour break, decreased at the ripe stage and then rose again at the ripe stage (Table 1). Nevertheless, the content at the senescence was statistically similar to the content at colour break, which was the highest recorded of the varieties. This is an indication that Black NS was clearly superior in terms of fructose content compared to the other varieties. There was a continuous, steady increase in glucose content for all the varieties from the ripe stage through to senescence. Only JKUAT variety showed a decrease in the glucose content at senescence, though this was not statistically significant from the ripe stage which recorded the highest content for this particular variety. Glucose content was very low at the green and colour break stages for all the varieties. However, on hitting the ripe stage, the content observed a major spike. Compared to the other varieties, KARLO Agric was significantly inferior in glucose content, scoring the highest value of $22.20 \mathrm{mg} / 100 \mathrm{~g}$ at senescence compared to Giant NS' $172.44 \mathrm{mg} / 100 \mathrm{~g}$ at the same stage. 
TABLE 1: DEVELOPMENTALLY-RELATED CHANGES IN SUGARS (MG/100G) IN FOUR SELECTED VARIETIES OF AFRICAN NIGHTSHADE (SOLANUM NIGRUM L.) EDIBLE BERRIES

\begin{tabular}{|c|c|c|c|}
\hline Variety & Fructose & Glucose & Sucrose \\
\hline \multicolumn{4}{|l|}{ Green } \\
\hline KALRO Agic. & $17.00 \pm 0.62^{\mathrm{de}}$ & $0.25 \pm 0.00^{\mathrm{a}}$ & ND \\
\hline Black N.S. & $24.21 \pm 0.18^{\mathrm{hi}}$ & $3.28 \pm 0.02^{\mathrm{a}}$ & ND \\
\hline Giant N.S. & $14.99 \pm 0.46^{\mathrm{c}}$ & $2.78 \pm 0.05^{\mathrm{a}}$ & ND \\
\hline JKUAT Impr. & $16.29 \pm 0.70^{\mathrm{cd}}$ & $2.38 \pm 0.03^{\mathrm{a}}$ & ND \\
\hline \multicolumn{4}{|l|}{ Colour Break } \\
\hline KALRO Agric. & $18.74 \pm 0.53^{\mathrm{ef}}$ & $11.74 \pm 0.07^{\mathrm{a}}$ & $0.60 \pm 0.01^{\mathrm{a}}$ \\
\hline Black N.S. & $30.65 \pm 0.20^{\mathrm{k}}$ & $8.95 \pm 0.14^{\mathrm{a}}$ & $2.00 \pm 0.06^{\mathrm{a}}$ \\
\hline Giant N.S. & $21.23 \pm 0.94^{\mathrm{g}}$ & $7.76 \pm 0.28^{\mathrm{a}}$ & ND \\
\hline JKUAT Impr. & $16.76 \pm 0.07^{\mathrm{d}}$ & $2.38 \pm 0.07^{\mathrm{a}}$ & $0.70 \pm 0.01^{\mathrm{a}}$ \\
\hline \multicolumn{4}{|l|}{ Ripe } \\
\hline KALRO Agric. & $27.03 \pm 1.13^{\mathrm{j}}$ & $20.17 \pm 0.70^{\mathrm{a}}$ & $252.3 \pm 8.50^{\mathrm{d}}$ \\
\hline Black N.S. & $25.79 \pm 0.45^{\mathrm{ij}}$ & $156.29 \pm 62.72^{\mathrm{bc}}$ & $283.8 \pm 6.42^{f}$ \\
\hline Giant N.S. & $29.36 \pm 0.66^{\mathrm{k}}$ & $165.13 \pm 5.13^{\mathrm{c}}$ & $267.8 \pm 0.32^{\mathrm{e}}$ \\
\hline JKUAT Impr. & $20.07 \pm 0.61^{\mathrm{fg}}$ & $125.07 \pm 3.85^{\mathrm{bc}}$ & $261.0 \pm 11.06^{\mathrm{de}}$ \\
\hline \multicolumn{4}{|l|}{ Senescence } \\
\hline KALRO Agric. & $13.15 \pm 0.66^{\mathrm{b}}$ & $22.20 \pm 0.37^{\mathrm{a}}$ & $66.00 \pm 2.58^{\mathrm{b}}$ \\
\hline Black N.S. & $29.35 \pm 0.42^{\mathrm{k}}$ & $161.45 \pm 7.00^{\mathrm{c}}$ & $388.40 \pm 7.40^{\mathrm{g}}$ \\
\hline Giant N.S. & $23.94 \pm 0.22^{\mathrm{h}}$ & $172.44 \pm 3.79^{c}$ & $211.30 \pm 3.90^{\mathrm{c}}$ \\
\hline JKUAT Impr. & $9.43 \pm 0.29^{\mathrm{a}}$ & $111.38 \pm 3.42^{b}$ & $206.20 \pm 3.17^{\mathrm{c}}$ \\
\hline
\end{tabular}

Values are Means \pm Standard Deviation. Values with different superscript letters along the same

column are significantly difference at $\mathrm{p}=0.05$ as assessed by Tukey's significant difference

$\mathrm{ND}=$ Not detected

The trends in reducing sugars in this study agree with previous works. A study on seabuckthorn berries indicated that glucose and fructose constituted nearly the whole of sugar fraction in the berries [23]. However, glucose was the major sugar. Cultivars showed different trends in sugars with ripening though at the end, all of them recorded decreasing sugar levels. The variability in sugar accumulation among different genotypes was also reported by [8].

In another study, juice made from the pomegranate fruits contained $12-16 \%$ sugar mainly comprising of fructose and glucose with the latter being more predominant [10,11]. A similar observation was made by Fawole and Opara [24] where fructose and glucose increased during maturation but with ratios of glucose to fructose $(\mathrm{G} / \mathrm{F})$ ranging from $0.67-0.85$ to $0.72-0.86$ in Bhangwa and Ruby fruits grown in South Africa, respectively. Al-maiman and Ahmad [10] further agreed by reporting that in 'Taifi' cultivar of pomegranate, glucose levels were higher than fructose at the unripe, half-ripe and full ripe stages of development. Davies and Robinson [25] indicated that during the ripening of grape berries, sucrose that is transported from the leaves accumulates in the vacuoles of the berries (sink cells) as glucose and fructose and this could explain the influx of the two sugars during fruit development.

No sucrose was detected at the green stage for all the varieties but traces were recorded at colour break for all the varieties except Giant NS. This was followed by a major spike at the ripe stage with the varieties recording values in the range of $252-$ $283 \mathrm{mg} / 100 \mathrm{~g}$. At senescence, there was a significant decrease in sucrose content for three of the varieties with the exception of Black NS which continued to record a significant rise in the content, peaking at 388 $\mathrm{mg} / 100 \mathrm{~g}$ at senescence, the highest value recorded for the sugars. Sucrose accumulation in the current study showed a trend where there was little or no traces in the first stages of development but observed a major hike during the senescence stage (overripe). 
This increase in sucrose is a deviation from previous studies on berries which did not report on the increase in sucrose. Besides the fact that sucrose is a major sugar in the fruit development $[7,14]$, this phenomenon could also be explained by the fact that sucrose is an important signal in the regulation of berry ripening as demonstrated by Jia et al. [1]. This study revealed that apart from the traditional understanding of the role of sugars in plants where they are metabolic resources for carbon skeleton construction and energy sources, sugar signaling could also be involved in other functions such as seed germination, embryogenesis, vegetative and reproductive growth as well as senescence $[1,26]$.

In the sink cells, the sucrose cycle is, also known as the sucrose-sucrose cycle or the futile sucrose cycle, is an important pathway [7]. The cycle involves the action of sucrose synthase and invertase for the liberation of hexoses (glucose and fructose). These hexoses are then phosphorylated and there is interconversion between hexose phosphates and UDP-glucose. Finally, there is the resynthesis of sucrose through the enzymes sucrose-6phosphate synthase (SPS) and sucrose-6-phosphate phosphatase $[7,14,26]$. This cycle allows for connection of sugar with other metabolic pathways such as the glycolysis, TCA cycle, starch and cellulose synthesis [7]. Since the biochemical regulation of the sucrose-sucrose cycle and the associated transport system is not fully understood [7], it can be hypothesized that the accumulation of sucrose in the African nightshade berries at senescence is as a result of under-regulation of sugar related enzymes and genes during deterioration at senescence. Consequently, the sucrose from the leaves is not converted to glucose and fructose and the sucrose-sucrose cycle stops. As such, sucrose accumulates in the sink cells in its initial form. Given that sugars in fruits are not only essential for fruit growth and development but also for the overall quality of the fruit [7], more studies could be carried out to investigate the accumulation of sucrose during senescence in Solanum nigrum edible berries.

\section{B. Colour}

Fruit colour is one of the appearance aspects that consumers use to evaluate for quality [2]. The colour characteristics of the berries were as indicated in Table 2. KARLO Agric., Giant NS and JKUAT varieties had similar colour characteristics in nearly all the stages of development.

High $\mathrm{L}^{*}$ values were recorded at the green stage but decreased as they ripened. Black NS, however, showed a different trend where the $\mathrm{L}^{*}$ value was small at the green stage but increased continuously to senescence. The $a^{*}$ value increased for all the varieties although Black NS still recorded higher values compared to the rest. KARLO Agric., Giant NS and JKUAT varieties had the highest a* values at colour break and then the value decreased to 1.57 to 1.77 while the value for Black NS increased to the last stage, reaching 46.23. These changes in colour are due to accumulation of anthocyanins in the berries [27] while the differences in colour parameters could be attributed to the fact that while all the varieties were green while unripe, Black NS acquired a bright orange colour upon ripening while all the other varieties acquired a purplish-black colour. This could have an impact on the acceptability of the berries by consumers $[2,28]$.

TABLE 2: COLOUR CHANGES IN 4 VARIETIES OF AFRICAN NIGHTSHADE EDIBLE BERRIES WITH RIPENING

\begin{tabular}{|c|c|c|c|}
\hline Variety & $\mathbf{L}^{*}$ & $a^{*}$ & $\mathbf{b}^{*}$ \\
\hline \multicolumn{4}{|l|}{ Green } \\
\hline KALRO Agric. & $66.47 \pm 19.19^{d}$ & $-12.53 \pm 0.93^{\mathrm{ab}}$ & $1.55 \pm 1.36^{\mathrm{a}}$ \\
\hline Black N.S. & $32.23 \pm 6.41^{\mathrm{ab}}$ & $-10.9 \pm 0.56^{\mathrm{b}}$ & $15.7 \pm 2.26^{\mathrm{b}}$ \\
\hline Giant N.S. & $53.77 \pm 4.04^{\mathrm{cd}}$ & $-17.57 \pm 0.38^{\mathrm{a}}$ & $27.13 \pm 0.72^{\mathrm{cd}}$ \\
\hline JKUAT Impr. & $44.53 \pm 1.66^{\mathrm{abc}}$ & $-14.77 \pm 2.60^{\mathrm{ab}}$ & $21.13 \pm 2.80^{\mathrm{bc}}$ \\
\hline \multicolumn{4}{|l|}{ Colour Break } \\
\hline KALRO Agric. & $38.8 \pm 0.75^{\mathrm{abc}}$ & $-1.27 \pm 0.31^{\mathrm{c}}$ & $4.57 \pm 0.95^{\mathrm{a}}$ \\
\hline Black N.S. & $41.63 \pm 0.83^{\mathrm{abc}}$ & $4.47 \pm 1.16^{\mathrm{d}}$ & $33.97 \pm 1.04^{\mathrm{d}}$ \\
\hline Giant N.S. & $35.7 \pm 1.15^{\mathrm{abc}}$ & $2.60 \pm 1.40^{\mathrm{cd}}$ & $3.90 \pm 3.30^{\mathrm{a}}$ \\
\hline JKUAT Impr. & $65.63 \pm 13.82^{\mathrm{d}}$ & $-12.33 \pm 5.33^{b}$ & $21.77 \pm 8.78^{\mathrm{bc}}$ \\
\hline \multicolumn{4}{|l|}{ Ripe } \\
\hline KALRO Agric. & $28.20 \pm 2.89^{\mathrm{d}}$ & $3.83 \pm 0.49^{\mathrm{d}}$ & $2.07 \pm 0.72^{\mathrm{a}}$ \\
\hline Black N.S. & $49.40 \pm 0.40^{\mathrm{bcd}}$ & $15.60 \pm 0.50^{\mathrm{e}}$ & $43.27 \pm 1.14^{\mathrm{e}}$ \\
\hline Giant N.S. & $33.20 \pm 0.70^{\mathrm{ab}}$ & $5.20 \pm 0.53^{\mathrm{d}}$ & $4.53 \pm 3.61^{\mathrm{a}}$ \\
\hline JKUAT Impr. & $29.03 \pm 1.81^{\mathrm{a}}$ & $3.63 \pm 1.15^{\mathrm{cd}}$ & $2.07 \pm 0.21^{\mathrm{a}}$ \\
\hline \multicolumn{4}{|l|}{ Senescence } \\
\hline KALRO Agric. & $28.23 \pm 0.37^{\mathrm{a}}$ & $1.87 \pm 1.26^{\mathrm{cd}}$ & $1.77 \pm 0.55^{\mathrm{a}}$ \\
\hline Black N.S. & $52.80 \pm 0.44^{\mathrm{cd}}$ & $21.60 \pm 0.20^{\mathrm{f}}$ & $46.23 \pm 0.32^{\mathrm{e}}$ \\
\hline Giant N.S. & $28.80 \pm 1.35^{\mathrm{a}}$ & $2.57 \pm 0.72^{\mathrm{cd}}$ & $1.67 \pm 0.49^{\mathrm{a}}$ \\
\hline JKUAT Impr. & $27.33 \pm 0.40^{\mathrm{a}}$ & $0.87 \pm 0.15^{\mathrm{cd}}$ & $1.57 \pm 0.45^{\mathrm{a}}$ \\
\hline
\end{tabular}

Values are Means \pm Standard Deviation.. Values with different superscript letters along the same column are significantly different at $p=0.05$ as assessed by Tukey's significant difference 


\section{Firmness}

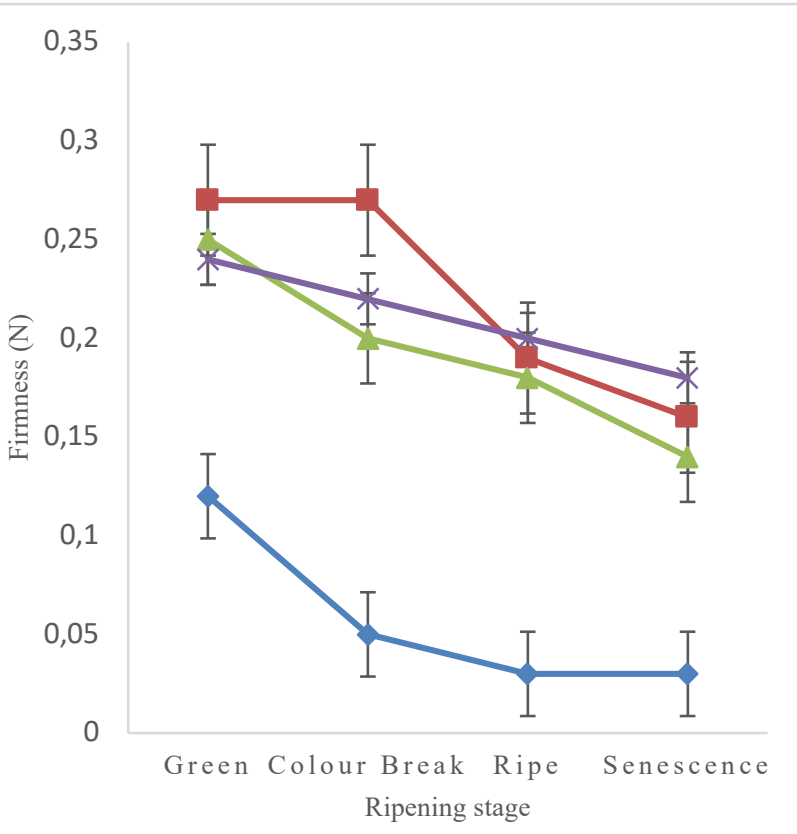

$\longrightarrow$ Black N.S Giant N.S KALRO $\longleftarrow$ JKUAT

Fig. 1: Changes in berry firmness of four varieties of Solanum nigrum against the ripening stages

Fruit ripening is achieved through chlorophyll degradation and cell wall lysis [29]. During ripening, fruit softening is a function of coordinated processes of modification of the polysaccharides making up the cell wall and the middle lamella, leading to the weakening of the structure [30] as well as an increase in ethylene production [31]. In this study, all the four varieties recorded a decrease in firmness from the green stage to senescence. Giant NS had the most firm fruits at colour break. However, it was observed, as shown in Figure 1, that Giant NS, KALRO Agric and JKUAT varieties were not significantly different in firmness of their fruits at the green, ripe and senescence stages. Black NS was significantly different from the other varieties at all stages, recording the lowest firmness values of all the varieties at all stages. This is consistent with the conclusion by Brummell et al. [32] that softening and textural changes that occur during ripening are characteristic of particular species. For all the varieties, fruit softening was initiated at veraison and remained on a downward trend to senescence, a trend that was also reported [32] while studying the cell wall changes in ripening of peach fruits.

Trends observed in this study correspond with previous related studies. Castelllarin and others [12] studied the changes in grapes and concluded that berry firmness reached peak at full grown but unripe stage and then decreased and remained on a stable decline upto the end of the study. This study showed that majority of the softening in grapes seemed to take place just prior to the change of colour. The possible reason for the softening could be cell wall modification [13]. While analyzing the changes in firmness of grape berries during ripening, Nunan and colleagues [33] observed that at veraison, there was a rise in the protein content and an approximate 3-fold increase in the hydroxyproline content.

Of the pectic polysaccharides, type 1 arabinogalactan decreased by about $80 \%$ from $20 \mathrm{~mol} \%$ to $4 \mathrm{~mol} \%$ of total cell wall. Galacturonan increased by almost 2-fold and became more soluble [33]. This is further corroborated by other workers [32] who concluded that softening of mature fruits prior to ripening was associated with depolymerization of matric glycans that are both loosely and tightly attached to cellulose as well as loss of Gal from cell wall fractions. This continued during ripening and was coupled by major losses of Ara from the loosely bound matric glycan fraction. At senescence, the excessive softening of peach fruits was associated with dramatic depolymerization of chelatorsoluble polyuronides. The depolymerization was facilitated by the increase in solubilization of the chelator-soluble polyuronides [32]. Given the consistency in the trends in berry ripening in this study and previous studies, it can be concluded that the changes can be attributed to changes in composition of cell wall polysaccharides as well as significant modification in specific polysaccharides. More studies can be carried out on the African nightshade berries to ascertain the specific changes that take place as they ripen.

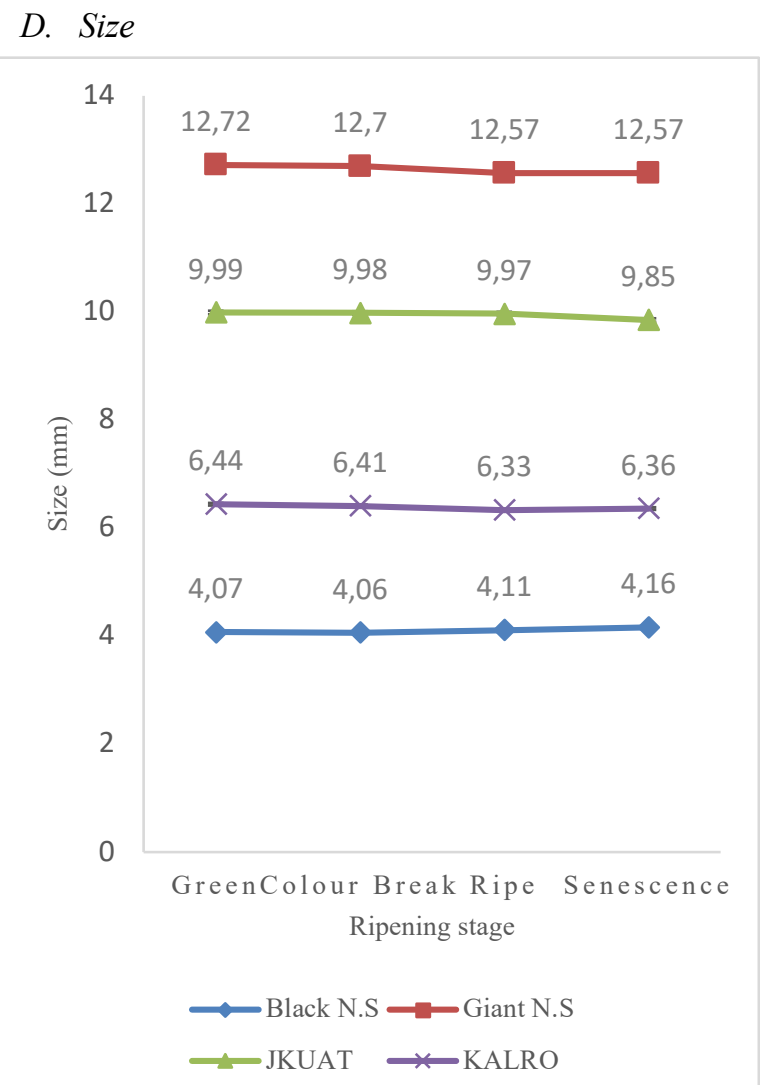

Fig. 2: Changes in berry size ( $\mathrm{mm}$ ) of four varieties of Solanum nigrum against the ripening stages

Berry sizes were as indicated in figure 2 . The berry sizes were significantly different amongst the varieties. There were very gradual decreases in berry size for the Giant NS, KALRO and JKUAT varieties. However, Black NS showed a different trend where the berry sizes seemed to increase slightly with each ripening stage. While the berry sizes were significantly different amongst the varieties at each stage, the size within each variety did not show any significant 
change in size with ripening. Previously, grape berries were recorded to increase in diameter and weight in the early development stages [12] but not in the latter stages of development. Fruit parts such as weight and volume are known to increase with development [24], which is the observation made in this study.

\section{CONCLUSION}

Findings from this study indicate that African nightshade edible berries have comparable characteristics with other fleshy, non-climacteric fruits that are commonly consumed in the household diet. They accumulate reducing sugars as they develop but have higher glucose than fructose fraction. Sucrose is present in high amounts at senescence. These characteristics could contribute to organoleptic quality and appeal to consumers. Black NS was considerably different from the other varieties, having a different colour, smaller size, higher sugar content and less firmness compared to the other varieties. This could imply that its application in the diet or other commercial purposes could be different from the others. Though not commonly consumed, the berries could be a valuable addition to the household diet through dietary diversification and for commercial exploitation through value addition and processing. However, research should be carried out to determine the exact pathways responsible for the ripening and accumulation of sugars in the berries.

\section{ETHICAL STATEMENTS}

Declaration of Conflicting Interests: The Authors declare that there is no conflict of interest

Ethical Review: The study does not involve any human or animal testing.

\section{ACKNOWLEDGEMENT}

Support for this research was made possible through a capacity building competitive grant Training the next generation of scientists provided by Carnegie Cooperation of New York through the Regional Universities Forum for Capacity Building in Agriculture (RUFORUM).

We are grateful to Mr. David Rasugu of Jomo Kenyatta University of Agriculture and Technology for his assistance during the chemical analyses.

\section{REFERENCES}

[1] H. Jia, Y. Wang, M. Sun, B. Li, Y. Han, Y. Zhao, ... W. Jia "Sucrose functions as a signal involved in the regulation of strawberry fruit development and ripening," New Phytologist, Vol. 198, pp. 453-465, 2013.

[2] A.A. Kader, "Fruit maturity, ripening, and quality relationships," in L. Michalczuk (Ed.), Int. Symp. on Effect of Pre- and Post Harvest Factors on Storage of Fruit. Acta Hortic., 1999, pp. 485:203-208.

[3] C. Davies and C. Böttcher, "Hormonal control of grape berry ripening." Glen Osmond, Australia: Commonwealth Scientific and Industrial Research Organization, 2009 https://doi.org/10.1007/97890-481-2305-6

[4] O.A. Fawole and U.L. Opara, "Changes in physical properties, chemical and elemental composition and antioxidant capacity of pomegranate ( cv . Ruby ) fruit at five maturity stages," Scientia Horticulturae, Vol. 150, pp. 37-46, 2013a.. https://doi.org/10.1016/j.scienta.2012.10.026

[5] S.Y. Wang, C. Chen and C.Y. Wang, "The influence of light and maturity on fruit quality and flavonoid content of red raspberries," Food Chem, Vol. 112, pp. 676-684, 2009 https://doi.org/10.1016/j.foodchem.2008.06.032

[6] X. Zhang, X. Wang, X. Wang, G. Xia, Q. Pan and R. Fan, "A Shift of Phloem Unloading from Symplasmic to Apoplasmic Pathway Is Involved in Developmental Onset of Ripening in Grape Berry," Plant Physiol., Vol. 142, pp. 220-232, 2006. https://doi.org/10.1104/pp.106.081430

[7] Li Mingjun, P. Li, F. Ma, A.M. Dandekar and L. Cheng, "Sugar metabolism and accumulation in the fruit of transgenic apple trees with decreased sorbitol synthesis," Hort. Res. Vol. 5, pp. 60-71, 2018. https://doi.org/10.1038/s41438-018-0064-8

[8] X. Tang, "Intrinsic change of physical and chemical properties of sea buckthorn (Hippophae rhamnoides) and implications for berry maturity and quality," The Journal of Horticultural Science and Biotechnology, Vol. 77(2), pp. 177-185, 2016. https://doi.org/10.1080/14620316.2002.11511476

[9] G. Zhang, Z. Xu, Y. Gao, X. Huang, Y. Zou, and T. Yang, "Effects of Germination on the Nutritional Properties, Phenolic Profiles, and Antioxidant Activities of Buckwheat," J. Food Sci, Vol. 80(118), pp. H1111-H1119, 2015. https://doi.org/10.1111/1750-3841.12830

[10] S.A Al-maiman and D. Ahmad, "Changes in physical and chemical properties during pomegranate ( Punica granatum L .) fruit maturation," Food Chem., Vol. 76, pp. 437-441, 2002.

[11] P. Legua, P. Melgarejo, M. Martinez and F. Hernandez, "Evolution of sugars and organic acid content in three pomegranate cultivars (Punica granatum L.)," Serie A, Seminaires Mediterraneens, Vol. 42, pp. 99-104, 2000.

[12] S.D. Castellarin, G.A. Gambetta, H. Wada, M.N. Krasnow, G.R. Cramer, E. Peterlunger, ... M.A. Matthews, "Characterization of major ripening events during softening in grape: turgor, sugar accumulation, abscisic acid metabolism, colour development, and their relationship with growth," J. Exp. Bot., Vol. 67(3), pp. 709722, 2016. https://doi.org/10.1093/jxb/erv483

[13] S.D. Castellarin, G.A. Gambetta, H. Wada, K.A. Shackel and M.A. Matthew, "Fruit ripening in Vitis vinifera: spatiotemporal relationships among turgor, sugar accumulation, and anthocyanin biosynthesis," J. Exp. Bot, Vol. 62(12), pp. 4345-4354, 2011. https://doi.org/10.1093/jxb/err150

[14] F. Lecourieux, C. Kappel, D. Lecourieux, A. Serrano, E. Torres, P. Arce-johnson and S. Delrot, "An update on sugar transport and signalling in grapevine," J. Exp. Bot, Vol. 65(3), Vol. 821-832, 2014. https://doi.org/10.1093/jxb/ert394

[15] M.S. Defelice, "The Black Nightshades, Solanum nigrum L - Poison, Poultice, and Pie," Weed Tech, Vol. 17(2), pp. 421-427, 2003.

[16] H. Sarma and A. Sarma, "Solanum nigrum L ., a Nutraceutical Enriched Herb or Invasive Weed ?" 2011 International Conference on Environment and BioScience, Vol. 21, pp. 105-109, 2011.

[17] C. Bvenura \& A.J. Afolayan (2016) Maturity effects on mineral concentration and uptake in Solanum nigrum L . L., Acta Agriculturae Scandinavica, Section B. - Soil \& Plant Sci, 64(8):657665. https://doi.org/10.1080/09064710.2014.953984

[18] A. Ribera-Fonseca, M. Noferrini, E. Jorquera-Fontena and A.D. Rombola, "Assessment of technological maturity parameters and anthocyanins in berries of cv. Sangiovese (Vitis vinifera L.) by a portable vis/NIR device," Scientia Horticulturae, Vol. 209, pp. 229$235,2016$.

[19] H. Lee and J. Lee, "Effects of Various Kinds of Salt on the Quality and Storage Characteristics of Tteokgalbi," Korean J. Food Sci. An., 34(5):604-613, 2014.

[20] M. Li, M. Chen, Y. Zhang, C. Fu, B. Xing, W. Li, ... X. Yang, "Apple Fruit Diameter and Length Estimation by Using the Thermal and Sunshine Hours Approach and Its Application to the Digital Orchard Management Information System," PLOS One, Vol. 10(4), pp. 1-13, 2015. https://doi.org/10.1371/journal.pone.0120124

[21] D.D. Leite, de F, Queiroz, M.J. de, R.M.F. de Figuiredo, A.R.N. Campos, D.C. Santos and T.L.B. de Lima, "Germination Impact in the Nutrition and Technological Properties of Jackfruit Seeds," Journal of Agricultural Studies, Vol. 8(1), pp. 79-100, 2020. https://doi.org/10.5296/jas.v8i1.15524

[22] M.A. Hayes, C. Davies and I.B. Dry, "Isolation, functional characterization, and expression analysis of grapevine ( Vitis vinifera L .) hexose transporters: differential roles in sink and source tissues*," Journal of Experimental Botany, Vol. 58(8), pp. 19851997, 2007. https://doi.org/10.1093/jxb/erm061

[23] A. Raffo, F. Paoletti and M. Antonelli, "Changes in sugar, organic acid, flavonol and carotenoid composition during ripening of berries of three seabuckthorn (Hippophae rhamnoides L.) cultivars," Eur Food Res Technol, Vol. 219, pp. 360-368, 2004. https://doi.org/10.1007/s00217-004-0984-4

[24] O.A. Fawole and U.L. Opara, "Developmental changes in maturity indices of pomegranate fruit: A descriptive review," Scientia 
Horticulturae, Vol. 159, pp. 152-161, 2013b https://doi.org/10.1016/j.scienta.2013.05.016

[25] C. Davies and S.P. Robinson, "Sugar Accumulation in Grape Berries," Plant Physiol, Vol. 111, pp. 275-283, 1996.

[26] S. Yamaki, "Metabolism and Accumulation of Sugars Translocated to Fruit and Their Regulation," J. Japan Soc. Hort. Sci, Vol. 79(1), pp. $1-15,2010$.

[27] L. Fuentes, C.R. Figueroa and M. Valdenegro, "Recent Advances in Hormonal Regulation and Cross-Talk during Non-Climacteric Fruit Development and Ripening," Horticulturae, Vol. 5(45), pp. 1-28, 2019

[28] B. Dobrzanski and R. Rybczynski, Color as a Quality Factor of Fruits and Vegetables, In J. et al Blahovec (Ed.), Physical Methods in Agriculture, New York, NY: Springer Science, pp. 376-377, 1999.

[29] S. Forlani, S. Masiero and C. Mizzotti, "Fruit Ripening: The role of hormones, cell wall modifications and their intersection with pathogens," J. Exp. Bot, Vol. 70(11), pp. 2993-3006, 2019.

[30] D.A. Brummell, "Cell wall disassembly in ripening fruit," Functional Plant Biology, Vol. 33, pp. 103-119, 2006.

[31] J. Kan, J. Liu and C.H. Jin, "Changes in cell walls during fruit ripening in Chinese 'Honey' peach," J. Hort. Sci. Biotech, Vol. 88(1), pp. 3013. https://doi.org/10.1080/14620316.2013.11512933

[32] D.A. Brummell, V.D. Cin, C.H. Crisosto and J.M. Labavitch, "Cell wall metabolism during maturation, ripening and senescence of peach fruit," Journal of Experimental Botany, Vol. 55(405), pp. 2029-2039, 2004. https://doi.org/10.1093/jxb/erh227

[33] K.J. Nunan, I.M. Sims, A. Bacic, S.P. Robinson and G.B. Fincher, "Changes in Cell Wall Composition during Ripening of Grape Berries," Plant Physiol. Vol. 118, pp. 783-792, 1998. 